\title{
Merdeka Belajar in the Point of View of Learning Technology in the Era of 4.0 and Society 5.0
}

\author{
Bambang Ismaya1, Indra Perdana², Ardian Arifin3, Siti Fadjarajani 4, Samuel \\ PD Anantadjaya5, Mas'ud Muhammadiah'
}

DOI : $10.35445 /$ alishlah.v13i3.556

\section{Article Info}

Key words:

Merdeka Belajar,

Learning Technology,

Era 4.0,

Society 5.0

Kata kunci:

Merdeka Belajar

TeknologiBelajar

Era 4.0

Masyarakat 5.o

\section{Abstract}

The purpose of this article is to describe the autonomous perspective on learning in the Industrial Revolution 4.0 and Society 5.0 eras. This new era provides both benefits and consequences for the eroding of human values. To minimize adverse effects while optimizing its consumption. The point of the study was to define the concept of Merdeka Belajar in the Industrial Revolution 4.0 and Society 5.0 eras. The descriptive-analytic method was combined with a literature review in this investigation. The study's findings highlight a need to strengthen technology's position in the industrial revolution 4.0 in order to foster a more prosperous and civilized human life order, as illustrated in Community Model 5.o. The Indonesian people, in particular, must get familiar with critical educational patterns in order to be prepared to enter the industrial revolution 4.0 and Society 5.0 eras.

\section{Abstrak}

Artikel ini bertujuan untuk mendeskripsikan sudut pandang Merdeka belajar di era Revolusi Industri 4.0 dan Society 5.0. Datangnya masa ini menimbulkan manfaat dan akibat bagi terkikisnya nilai-nilai kemanusiaan. Untuk mengurangi dampak negatif sekaligus mengoptimalkan pemanfaatannya. Tujuan dari penelitian ini adalah untuk mengetahui konsep merdeka Belajar dalam era revolusi Industri 4.0 dan Masyarakat 5.0. Metode yang digunakan dalam penelitian ini adalah metode analisis deskriptif dengan studi pustaka. Hasil penelitian menunjukkan perlunya peningkatan posisi teknologi dalam revolusi industri 4.0 untuk membangun tatanan kehidupan manusia yang lebih sejahtera dan beradab sebagaimana ditunjukkan dalam Model Masyarakat 5.o. Khususnya Masyarakat Indonesia perlu dibiasakan dengan pola pendidikan yang relevan, sehingga siap menembus era revolusi industri 4.0 serta Masyarakat 5.0.

\footnotetext{
${ }^{1}$ Un iv ersitas Singaperbangsa Karawang, Karawang, In donesia

Em ail: bambang.ismaya@fkip.unsika.ac.id

2 Univ ersity Palangkaraya, Palangkaraya, In donesia

Em ail: iperdana329@gmail.com

3 IKIP PGRI Pon tianak, Pontianak, In donesia

Em ail: ardian.arifin@yahoo.com

4 Univ ersitas Siliwangi, Tasikmalaya, Indonesia

Em ail: sitifadjarajani@unsil.ac.id

5 Un iv ersitas In ternational Liaison In donesia, Tangerang, In donesia

Em ail: spdanantadjaya@gmail.com

6 Univ ersitas Bosowa, Ma kassar, Indonesia

Em ail: m asud.muhammadiah@universitasbosowa.ac.id
} 


\section{INTRODUCTION}

The rapid evolution of information and communication technology brings extreme change to society and industry (Dziuban et al., 2018). Digital transformation is about generating new value and becoming a pillar of industrial policy in several countries. To estimate such global trends," Society 5. 0" was presented as the core concept in the 5th Basic Plan of Science and Technology, adopted by the Cabinet of Japan in January 2016 (Houtman, 2020). It was identified as one of Japan's development strategies. Society 5. o is also a core part of Investment Strategy for the Future (Vania Sasikirana, 2017). We are experiencing the 4th industrial revolution known as Industrial Revolution 4.0 (Kurniawan et al., 2019). This is a time of disruptive innovation that grows very rapidly to help create new markets. This innovation can also disrupt existing markets and even more powerfully take over existing technology. In the context of learning, it can also be called" Learning Period 4. o", which is a tough challenge experienced by educators-linked to learning period 4. o (Purwodani \& Praherdhiono, 2018).

Nadeem Makarim, Minister of Learning and Culture, delivered a speech at the peak of the 2019 national teacher day and the 74th Anniversary of PGRI, "Teachers Move Indonesia Forward, Creating Superior Human Energy Sources" (Ni Nyoman Lisna Handayani1, 2020). There are two priorities to increase Human Energy Resources in international competition: the first utilisation process, education, and the printing of student personality in an academy. Second, Indonesian language learning must begin to be independent and make the teacher the driving force. From the two statements above, it can be concluded that carrying out the learning process, focuses not only on artificial intelligence through connectivity in all activities but also on the human component as a learning driver. Without us realizing it, our learning has now entered society 5.0, which is currently offering the society a balancing act. The internet is not only for data but for life, a time when all technology is part of humans themselves, and the growth of technology can reduce inequality in humans and subsequent economic problems.

Society 5.0 is a Society where various needs are distinguished and crowded by providing the products and services needed in sufficient quantities to people who need them when they need them, and where everyone can receive excellent quality services and safe and vibrant life (Onday, 2019)(Atsushi Deguchi, Chiaki Hirai, Hideyuki Matsuoka \& Kohei Oshima, Mitsuharu Tai, 2018). Looking back at human history, we can define the various stages of society. Society 1. o is defined as groups of people who seek and gather in harmonious coex istence with nature; Society 2. o forms groups sourced on agricultural cultivation, organizational as well as nation-building; Society 3. $\mathrm{o}$ is a Society that promoted industrialization through the industrial revolution, enabling mass creation; and Society 4.0 is a data Society who realizes the increase in added value by connecting intangible relics as a data network. In this evolution, Society 5.0 is the community data formed above Society 4. o, which aims to make the poor prosperous (Polat \& Erkollar, 2021)(Önday, 2020).

Society 5.0 aims to produce a human-centred Society where economic development and the resolution of Society challenges are achieved. People can enjoy an excellent quality of life that is entirely active and safe (Suwandi, 2020; Santoso et al., 2020). This society wants to appear in detail for various needs of people, regardless of region, age, gender, language, by providing the necessary objects and services. The key to its realization is the combination of cyberspace and the real world to create quality information and generate new values and solutions to solve challenges(Fukuyama, 2018).

Japan's challenges, such as an ageing population, are 26.3 per cent over the age of 65 , shrinking birthrates, shrinking populations, and ageing infrastructure; Japan's national vision is to cultivate new human-centred Society; While Society 5. o is Japan's development strategy, it is not limited to Japan, because the challenge, in conclusion, is to be experienced by many other countries(Fukuda, 2020)(Holroyd, 2020). To put this in a global perspective is expected that in all 
the world, more than 20 per cent of the population will be over 60 years old by 2050. This means, despite the extraordinary numbers in Japan now, that the whole country, including Indonesia, should look at what Japan is trying and how Society 5 is doing. These o works because we want to have a lot of wisdom to learn from the perspective of an ageing population- and more. For the Cabinet Office of Japan, Society 5. o is defined as a human-centred Society that balances economic progress with solving social problems through a system that integrates cyberspace and body space 4. 0 Then why did Society 5 arise(Yang \& Gu, 2021).

Study against the industrial revolution 4.0 , which is considered potential in degrading human position made Japan give birth to a concept namely Society 5. o (Setiyadi, n.d.; Tadjbakhsh \& Chenoy, 2007). This concept is expected to make artificial intelligence want to transform considerable information collected through the internet in all areas of life into something new wisdom, hoping to improve human expertise in opening opportunities for humans. Aims to produce a society that can solve various social challenges by incorporating industrial revolution innovation 4.0 ( e.g. IoT, big data, artificial intelligence, robots, and economic sharing) into every industry and social life (Fathi et al., 2019; Salgues, 2018). By carrying out that, the future society will become Society where new values and services are constantly created, making human life more harmonious and prolonged. This is Society 5. o, an amazingly smart society. Japan wants to take the lead to make this happen in front of other countries in the world. This paper aims to describe Merdeka Belajar from the point of view of learning technology in the era of 4.0 and Society 5.0.

\section{METHODS}

The research used highlights the Merdeka Belajar the point of view of learning technology in the 4.0 and Community 5.0 eras. In this regard, the authors conducted research using the descriptive analy sis method with a literature study. The research design includes: 1 ) topic selection, 2) data exploration, 3) ensuring the focus of research is based on the data that has been obtained, 4) sources of information collected in the form of empirical data or information sourced from research articles and other literature that support the theme of this research, 5) Reading literature sources, 6) Making research notes, 7) Digesting research notes, 8) Compiling reports. Information collection methods used are editing, organizing, and discovery, instead of making information analysis methods using deductive and interpretive analysis. This study aims to describe the position of Merdeka Belajar in terms of learning technology in Era 4.0 and Community 5.0.

The study is also structured into a series of steps (described below) that culminate in developing a database containing all the characteristics of the selected papers. It's possible to decipher the details using different viewpoints based on the database. This gives us a complete picture of the situation. Characteristics of Merdeka Belajar from the point of view of learning technology in the 4.0 era and community literature 5.0 from all over the world. Figure 1 depicts the entire rebuilding process.

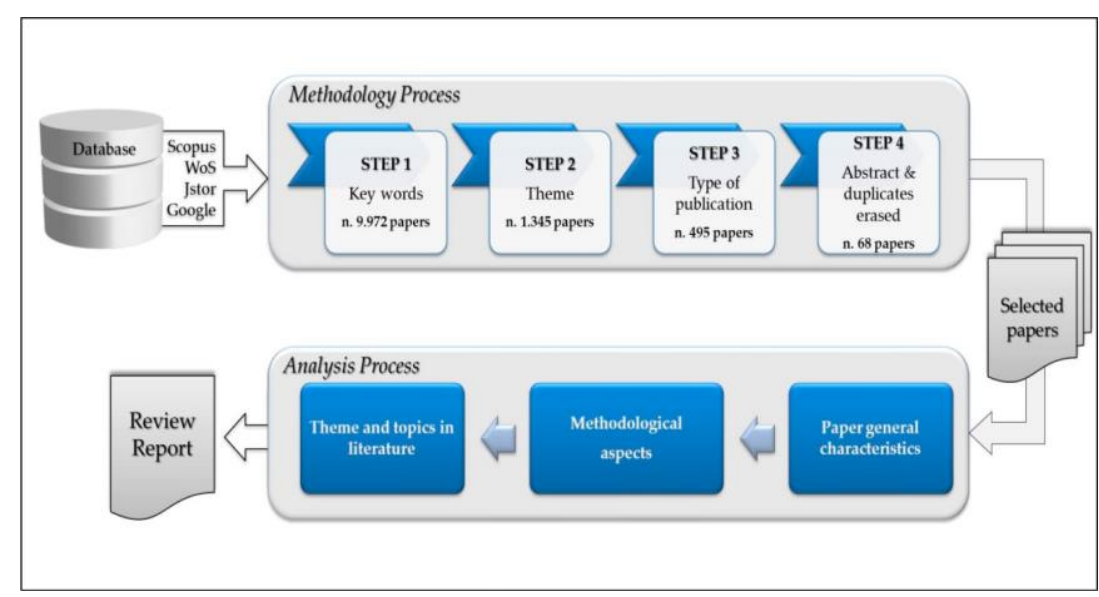

Figure 1. Review Proces: Note Our Elaboration

Page 1779 of 1785 


\section{FINDINGS AND DISCUSSION}

\section{The direction of the new change of the phenomenon of Merdeka Belajar}

The concept of Merdeka Belajar, initiated by the Minister of Education and Culture Nadeem Makarim, is not a new topic. Education activists have long sparked the topic. One of them was initiated by education activists in the Gathering of Nusantara Educators who far- far away transported the theme of Merdeka Belajar became the main topic in each activity and dialogue. Nevertheless, appreciation is given because it has given birth to innovations.

Merdeka Belajar is a flagship program initiated by the Minister of Education and Culture in 2019. What is meant by Merdeka Learning in its strategic policies are National Standardized School Examinations (USBN), National Examinations (UN), Learning Implementation Plans (RPP) and Zoning. But from the other side, Merdeka Belajar is not only in the classroom. It can answer teacher problems, it can only be limited to raising hands when given a problem, but Merdeka Belajar is a spirit and noble ideals that transcend the boundaries of the classroom and the world. This will be formed when an educator has the freedom to teach. One question that must be answered together is whether we as educators feel free to teach. This is the initial concept in realizing freedom in learning. The principle of Merdeka Belajar is a free act in expressing learning events without any limitations and criticisms. Many groups of educators and institutions that overshadow it, fixated on methods and goals, cannot distinguish between methods and goals. Many are trapped in the Education administration system, busy preparing files, trapped in bureaucratic requirements, accreditation, grades, and exams, all just methods of making goals and priorities.

Merdeka Belajar dialogue is easy to say and difficult to try. Merdeka Belajar is inseparable from commitment, independence, and expertise to make it happen. Commitment in learning is early capital in achieving the ideals and objectives as the mandate of the law and the purpose of national education. Independent in Learning Freedom as a foundation to achieve goals, this is also difficult to try. The majority are only stuck on manipulation with terms and positions that make it difficult to learn independence. All finish at the place to give input as well as the place of consultation. The skill of realizing is a big obstacle to being able to lead to a change in education. An educator does not have to learn from an expert or an education expert. Teachers do not need perfect figures and experts. A teacher is very efficient in learning from teachers who have faced failure so successful and other teachers who practice what is learned. A teacher dares to learn not just to recognize but to practice the results that can and can be transferred to others. Merdeka Belajar can be interpreted as learning that does not pursue the target of coercion. Learning takes time that certainly does not have time to decrease from various innovations. Learners need something different from teachers. The competence of learners not only develops in the classroom but also in the learning area. Competence is not people's, but that competence develops with the site. As an independent human being, there is nothing different and cleavage in learning. The whole variety is just a different position of each. Freedom Learn and Learn Freedom is, all the same, just various ordinances and systems.

Merdeka Belajar is one of Nadeem Makarim's initiative programs to create a happy learning atmosphere, both for students and teachers. The purpose of Merdeka Belajar is so that teachers, students, and parents can find a comfortable atmosphere. Merdeka Belajar is if education is obliged to produce a happy atmosphere. National exams that have been the gateway for students entering a more significant level will be abolished in 2021 and replaced with minimum competency assessments and personality surveys. The implementation of the UN is thought to be less fitting because it is more urgent for students to memorize the subject matter, not understand it. National exams are also considered to be a source of mental pressure for students, especially parents and teachers, because there are demands for achieving great grades. The existence of the UN that prioritizes academic value achievement is considered contrary to the principle of education itself, which also requires psychological aspects as well as the growth of student character. About the 
ineffectiveness of this UN was also surveyed PB Persatuan Guru Republik Indonesia (PGRI) in 2012. As a result, if $70 \%$ of Society and teachers agreed unremoved.

The UN format replacement program also found the green light from Commission X DPR RI. However, some reported fearing teachers were unprepared for the new assessment system. There are some considerations, among others found some schools that may not be ready to be given the freedom to make their assessment system because of the lack of facilities and quality of teachers. It is feared that this could exacerbate Education inequality. Various assumptions arise from education observers. Some questions about the standards will be applied nationally if national tests are scrapped. Others consider this policy makes teachers freer in assessing their students. Another matter that is no less means an increase in the competence of teachers. The success of the Merdeka Belajar program is to be determined by the competence of teachers whose condition has not been thorough.

\section{Merdeka Belajar and Society 5.o}

The rapid technological innovation that continues to face progress is about to change social life. Virtual space and bodies are no longer bordering, so that the attitudes and lifestyles of Society want to undergo significant transformation. The position of technology has become a human need every day in transacting, socializing, buying, selling, and talking. This concept will be spoken with Society 5. o. It is a concept in technology-based Society in balancing the growth of economic progress and social cases with systems that integrate cyber and physical. Or using other Societies who can use technology in the era of industrial revolution 4.0 in solving social problems. Extensive information, the Internet of Things (IoT), and Artificial Intelligence (AI) will be very fully functional at this time. Concept society 5. 0 aims so that Society can enjoy a life of excellent quality.

Japanese officials believe there are a variety of issues to be concerned about as the population continues to shrink year after year, resulting in reduced productive age. These include a lack of labor to reduce productivity, residents who live far from the city wanting difficulties in transportation and mobility, development wanting to shrink due to a lack of reliable labor, and a variety of issues to be concerned about. As a result, Japan must innovate in order to overcome the situation in its country through the use of technology.

Society 5.0 is the $5^{\text {th }}$ Science and Technology Plan initiated by the Japanese government as a dreamed future Society. Technological innovations that continue to face progress will change social life. Virtual and physical spaces no longer border, so that the attitudes and lifestyles of Society will face significant transformation. The position of technology has become a human need every day in transacting, socializing, buying, selling, and talking. This concept will be spoken with Society 5.0

\section{The Concept of Merdeka Belajar}

Merdeka Belajar is a form of revised provisions in restoring the essence of an assessment. For the Department of Learning and Culture, 2020. The implementation of free learning is freer. Learning institutions have autonomy in bureaucracy, such as lecturers who are freed from the bureaucracy that makes it difficult and students who are given flexibility in sorting out the field of science favoured. Through his address celebrating the National Teacher's Day on November 25, 2019, the Minister of Learning and Culture said that the core of Merdeka Belajaris schools, teachers, and students who have flexibility in the matter of innovating, free to learn independently and creatively.

Merdeka Belajar also speaks independence in thinking, which is the essence of freedom of thought that begins with the teacher. If this matter is not entwined with the teacher, it can not be run on the student participants. Senators inform this subject of DPD/MPR RI 20192024 , Professor. Doctor. Hj. Sylviana Pure, SH, Meter. Sang in the National Seminar " Merdeka Belajar: In Reaching Indonesia Forward 2045" which was held on March 10, 2020 at the State University of Jakarta (Sherly et al., 2020)(Widiyono et al., 2021). Merdeka Belajar is a new provision program 
from the Ministry of Education and Education launched by Nadiem Anwar Makarim to produce a happy and exciting learning atmosphere without being burdened with certain values and achievement goals.

\section{Learning in Era 4. 0}

Penetrated the 21 century, which is similar to the Industrial Revolution 4 . o, accompanied by a paradigm shift. The National Education Association has recognized 21st-century expertise as a "4Cs." The $4 \mathrm{Cs}$ "include critical thinking, creativity, communication, as well as cooperation. Critical thinking skills are the skills to carry out various analyzes, evaluations, assessments, reconstructions, decision-making leading to rational and logical actions(Yuliati \& Lestari, 2018).

There are also six trends in the xxi century (Siregar et al., 2020). Early on, the digital revolution proliferated. It influences various social life, but it can change civilization, culture, and learning. Second, globalization can strengthen integration between parts of the world, accompanied by the rapid growth of data and communication technology. Third, globalization can lead to forming a flat world, with almost no space free from the influence of regional or international areas. Fourth, the subject of new matter is very flash outdated or intertwined very lightning deprecation process. The world is kind of running around with discoveries emerging. Fifth, the growth of new communities such as the knowledge society of data Society and networking society. Society put the ability of data and networks as a meaningful capital. Sixth, the increasing demands of creativity and innovation as the capital of insiders experienced a competition.

Industrial Revolution 4. o some meaningful subjects need to be observed, such as a speed of change from one period to the next. Starting from the industrial revolution 1. o, 2. o, 3. o, which ranges from 100 years at each stage (Piccarozzi et al., 2018). On the contrary from the industrial revolution, 3. $\mathrm{o}$ leads at 4 . $\mathrm{o}$ its development lasted more lightning is less than 50 years. This issue shows that the technology is correct. Actual growth continues to be lightning as well as rapid. The changing demands of the need can perforate the industry to make innovation skills that match the requirements, meaning many types of work that quickly disappear because there are no more consumers or no longer needed because technology has replaced them. This subject led to the industrial revolution 4. o calls it Disruption Masa. The disappearance of a type of work, on the other hand, is influenced by a demand that can introduce new types of jobs that can indirectly open new positions. Industrial Revolution 4. o can urge learning institutions to get acquainted with the new curriculum or fix the old one.

\section{Living in Society 5. o}

Society 5 . $\mathrm{o}$ is a concept initiated by the Japanese government by considering aspects of technology to facilitate human life. However, this idea is also supported by considering humanities aspects so that a balancing concept is obtained in implementing the technology. To reach a community of Society that is defined as extraordinarily smart society, needed a variety of future services in various zones. This subject can be crowded with solid technological expertise. There are competent human energy sources in every field to carry out their profession digitally and contribute to providing better services for Society.

Industry 4.0 has been widely known to the public and has become a destination for technology development in various zones and regions. Often the humanitarian aspect is missed. Therefore, in carrying out planning, e.g. Engineering Design needs a process of user experience research so that the results are made (both products and services) meet the will and needs of customers so that the results become the right target. For example, in the Process of Design Thinking, there is a stage of Empathize, which is how the design is tried first by trying to empathize with potential users overwriting the subject to be made. This process wants to test whether the 
product or service to be made to solve the issue of the case or not, and if resolved the case, how much and how useful the result.

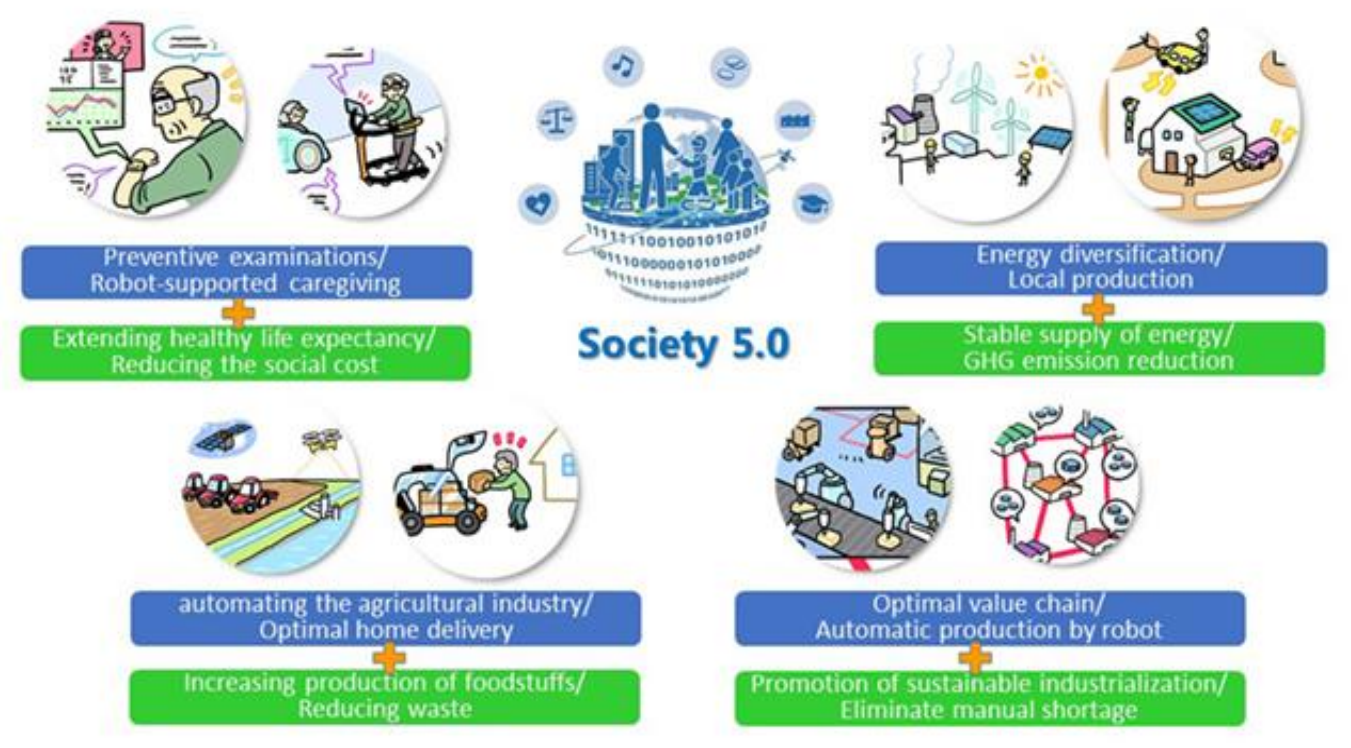

Figure 2. Community Example 5.0

Society 5.0 is an idea in hopes of resolving the issue. However, it still takes much growth in terms of technology to pick up this fifth term. Can carry out a massive revolution, there needs to be a solid capital. In this regard, the quality of human energy sources is a crucial subject in forming an integrated system. That suits your needs, if all energy sources are adequate, it is natural to dream of turning the world into Society 5. o is no longer an impossibility. This matter is very likely. Reviewing the various technological growths in all parts of the world is lightning, accompanied by new discoveries in technology that can facilitate human work and life.

\section{CONCLUSION}

It is possible to conclude from the findings of the aforementioned study that Merdeka Belajar, from the perspective of learning technology in the period of Industrial Revolution 4.0 and Society 5.0, is extremely significant in terms of sharing facilities and achieving independence in the period of the Industrial Revolution 4.0 and Society 5.0. The establishment of real-world learning programs that include sessions on management, utilization, development, assessment, and planning and processes is essential. Learning technology from the perspective of the Fourth Industrial Revolution and Society 5.0 is critical for teachers and lecturers to understand the nature of the learning technology they are utilizing. Teachers and lecturers cannot only identify learning technology as a feature, machine, computer, or other product, but learning technology must also tower over the systems and processes that lead to the desired results. Educating kids is intended to be more efficient and successful than it has ever been. It is also supposed to be more comprehensive, delivered faster, and have greater relevance for students than it has ever been. The study's shortcomings include the fact that not all schools can execute the concept of independent learning satisfactorily. A lack of human resources exists, implying that the situation must be improved shortly. This research can be used as a reference or input to assist researchers in conducting even better research in the future. 


\section{REFERENCES}

Atsushi Deguchi, Chiaki Hirai, Hideyuki Matsuoka, T. N., \& Kohei Oshima, Mitsuharu Tai, and S. T. (2018). What Is Society 5.o? SpringerOpen.

Dziuban, C., Graham, C. R., Moskal, P. D., Norberg, A., \& Sicilia, N. (2018). Blended learning: the new normal and emerging technologies. International Journal of Educational Technology in Higher Education, 15(1), 3. https://doi.org/10.1186/s41239-017-0087-5

Fathi, M., Khakifirooz, M., \& Pardalos, P. M. (2019). Optimizationin Large Scale Problems: Industry 4.o and Society 5.o Applications (Vol.152). Springer Nature.

Ferreira, C. M., \& Serpa, S. (2019). What is Society 5.0? Digital Society and Social Dynamics, 21.

Fukuda, K. (2020). Science, technology and innovation ecosystem transformation toward society 5.O.InternationalJournal of Production Economics, 220, 107460.

Fukuyama, M. (2018). Society 5.0: Aiming for a New Human-centered Society. Japan SPOTLIGHT, 27(August), 47-50.

Holroyd, C. (2020). Technological innovation and building a ‘super smart'society: Japan's vision of society 5.0. Journal of Asian Public Policy, 1-14.

Houtman. (2020). Merdeka Belajar Dalam Masyarakat 5.o. Prosiding Seminar Nasional Pendidikan Program Pascasarjana Universitas Pgri Palembang 10 Januari 2020, 39-46.

Kurniawan, A., Mukhadis, A., \& ... (2019). 21st Century Skills sebagai Upaya Pengembangan Kapabilitas Siswa SMK di Fourth Industrial Revolution Era. Jurnal Pendidikan: Teori ..., 857-862.

Ni Nyoman Lisna Handayani1, N. K. E. M. (2020). Pembelajaran Era Disruptif Menuju Era Society 5.o (Telaah Perspektif Pendidikan Dasar) Ni. International Seminar Proceeding, 3(2252), 58-66.

Onday, O. (2019). Japan's Society 5.o: Going Beyond Industry 4.o. https://doi.org/10.4172/21516219.1000389

Önday, Ö. (2020). Society 5.0-Its Historical Logic and Its Structural Development. Journal of Scientific Reports, 2(1), 32-42. https://doi.org/10.5281/zenodo.3731954

Piccarozzi, M., Aquilani, B., \& Gatti, C. (2018). Industry 4.o in management studies: A systematic literature review. Sustainability (Switzerland), 1O(10), 1-24. https://doi.org/10.3390/su10103821

Polat, L., \& Erkollar, A. (2021). Industry 4.o vs. Society 5.o. Lecture Notes in Mechanical Engineering, 333-345. https://doi.org/10.1007/978-3-030-62784-3_28

Purwodani, D. L., \& Praherdhiono, H. (2018). Prospek Pengembangan Lingkungan Belajar Digital untuk Generasi Z di Era Industri IV. Jurnal Pendidikan, 3, 930-934.

Salgues, B. (2018). Society 5.o: industry of the future, technologies, methods and tools. John Wiley \& Sons.

Santoso, M. B., Irfan, M., \& Nurwati, N. (2020). Transformasi Praktik Pekerjaan Sosial Menuju Masyarakat 5.o. Sosio Informa, 6(2), 170-183.

Setiyadi, D. B. P. (n.d.). Religious Values in Javanese Poetry Text as The Fundamental Education Capital for Society 5.O.

Sherly, S., Dharma, E., \& Sihombing, H. B. (2020). Merdeka belajar: kajian literatur. UrbanGreen Conference Proceeding Library, 1, 183-190.

Siregar, N., Sahirah, R., \& Harahap, A. A. (2020). Konsep Kampus Merdeka Belajar di Era Revolusi Industri 4.o. Fitrah: Journal of Islamic Education, 1(1), 141-157.

Suwandi, S. (2020). Implementasi Pembelajaran Abad Ke-21 Dan Tantangannya Untuk Berperan Dalam Masyarakat 5.o. Prosiding Seminar Nasional Program Pascasarjana Universitas PGRI Palembang.

Tadjbakhsh, S., \& Chenoy, A. (2007). Human security: Concepts and implications (Vol. 51). Routledge. 
Vania Sasikirana, Y.T. H. (2017). Urgensi Merdeka Belajar Di Era Revolusi Industri 4.o Dan Tantangan Society 5.o. Seminar Nasional: Jambore Konseling 3, oo(oo), XX-XX. https://doi.org/10.1007/XXXXXX-XX-0000-00

Widiyono, A., Irfana, S., \& Firdausia, K. (2021). Implementasi Merdeka Belajar Melalui Kampus Mengajar Perintis Di Sekolah Dasar. MetodikDidaktik: Jurnal Pendidikan Ke-Sd-An, 16(2). Yang, F., \& Gu, S. (2021). Industry 4.o, a revolution that requires technology and national strategies. Complex \& Intelligent Systems, 1-15.

Yuliati, S. R., \& Lestari, I. (2018). Higher-Order Thinking Skills (Hots) Analy sis Of Students In Solving Hots Question In Higher Education. Perspektif Ilmu Pendidikan, 32(2), 181-188. 